Correspondence

Roger C. Levesque

rclevesq@rsvs.ulaval.ca

Received 3 July 2007

Revised 10 April 2008

Accepted 14 April 2008

\title{
Functional genomics of PycR, a LysR family transcriptional regulator essential for maintenance of Pseudomonas aeruginosa in the rat lung
}

\author{
Irena Kukavica-Ibrulj, ${ }_{1}^{1}$ François Sanschagrin, ${ }^{1}$ Ashley Peterson, ${ }^{2}$ \\ Marvin Whiteley, ${ }^{2}$ Brian Boyle, ${ }^{3}$ John MacKay ${ }^{3}$ and Roger C. Levesque ${ }^{1}$ \\ ${ }^{1}$ Centre de Recherche sur la Fonction, Structure et Ingénierie des Protéines, Biologie Médicale, \\ Faculté de Médecine, Université Laval, OC G1K 7P4, Canada \\ ${ }^{2}$ Department of Microbiology and Immunology, University of Oklahoma, Health Sciences Center, \\ Oklahoma City, OK 73104, USA \\ ${ }^{3}$ Centre d'étude de la forêt, Pavillon Charles-Eugène Marchand, Université Laval, OC G1K 7P4, \\ Canada
}

\begin{abstract}
The human opportunistic pathogen Pseudomonas aeruginosa is the major cause of morbidity and mortality of cystic fibrosis patients and is responsible for a variety of infections in compromised hosts. Using PCR-based signature-tagged mutagenesis, we identified a $P$. aeruginosa STM5437 mutant with an insertion into the PA5437 gene (called pycR for putative pyruvate carboxylase regulator). PycR inactivation results in 100000 -fold attenuation of virulence in the rat lung in vivo. PycR has the signature of a transcriptional regulator with a predicted helix-turn-helix motif binding to a typical LysR DNA binding site in the PA5436 (pycA)-PA5437 (pycR) intercistronic region. Two pyruvate carboxylase subunits ( $p y c A$ and $p y c B$ ) are divergently transcribed upstream of $p y c R$. Transcriptional start sites of $p y c R$ and $p y c A$ are located at -127 and $-88 \mathrm{bp}$ upstream of their initiation codons with Shine-Dalgarno and putative promoter sequences containing -10 and -35 sequences. The DNA binding of PycR was confirmed by DNA mobility shift assay. Genome-wide transcriptional profiling and quantitative real-time PCR (qRT-PCR) indicated that the genes differentially regulated by PycR include two pyruvate carboxylase genes and genes necessary for lipid metabolism, lipolytic activity, anaerobic respiration and biofilm formation. PycR is a regulator with pleiotropic effects on virulence factors, such as lipase and esterase expression and biofilm formation, which are important for maintenance of $P$. aeruginosa in chronic lung infection.
\end{abstract}

\section{INTRODUCTION}

The versatile and ubiquitous opportunistic pathogen Pseudomonas aeruginosa causes infection in immunocompromised individuals and in cystic fibrosis (CF) patients, and is highly resistant to antibiotics (Rukholm et al., 2006). The pathogen produces a large variety of both

Abbreviations: CF, cystic fibrosis; $\mathrm{Cl}$, competitive index; LTTR, LysR-type transcriptional regulator; MFS transporter, major facilitator superfamily transporter; PM, Phenotype MicroArray; qRT-PCR, quantitative real-time PCR; QS, quorum sensing; STM, signature-tagged mutagenesis.

A supplementary table listing the PCR primers used and a supplementary figure showing a transcriptome analysis of genes differentially regulated by $P$. aeruginosa PycR are available with the online version of this paper.

The microarray data for this paper have been deposited in ArrayExpress (http://www.ebi.ac.uk/arrayexpress) with accession number E-MEXP1591. cell-associated and extracellular virulence factors. Pathogenesis of $P$. aeruginosa is not defined by a single virulence factor, but by the precise and delicate interplay between different highly regulated factors, leading to efficient colonization and biofilm formation, tissue necrosis, invasion and dissemination through the vascular system, as well as activation of both local and systemic inflammatory responses. Despite detailed knowledge of extracellular and several surface-associated proteins, many virulence factors essential for pathogenicity, and the mechanisms by which they coordinately function during pathogenesis, remain to be elucidated.

There are at least 498 genes encoding transcriptional regulators or putative regulators in the genome of $P$. aeruginosa (www.pseudomonas.com), and the biological functions of most of these regulators remain largely uncharacterized. There are 125 putative LysR-type transcriptional regulators (LTTRs), which are similarly sized, 
autoregulatory proteins that presumably evolved from a distant common ancestor, diverging into subfamilies found in diverse prokaryotic genera (Schell, 1993). Several $P$. aeruginosa virulence genes have been shown to be under the control of LTTRs. For example, MvfR positively regulates the production of elastase and phospholipase, autoinducers, homoserine lactone (PAI I), Pseudomonas quinolone signal (PQS) and phenazine biosynthesis (Wade et al., 2005). Exotoxin A production in $P$. aeruginosa is a highly regulated process that involves several genes, including the LTTR PtxR (Carty et al., 2003). P. aeruginosa strains infecting patients with $\mathrm{CF}$ acquire a mucoid phenotype due to overproduction of alginate, and the key enzyme in alginate synthesis is $\operatorname{AlgD}$, which has been shown to be under the control of the LTTR CysB (DelicAttree et al., 1997). The LTTRs from other bacterial pathogens have also been found to be implicated in transcriptional regulation of various virulence and antibiotic resistance factors. For example, AphA is a quorum sensing (QS)-regulated activator that initiates the virulence cascade in Vibrio cholerae by cooperating with the LTTR AphB (Kovacikova et al., 2005).

Using an insertional mutation-based screening method for the simultaneous identification of virulence genes important for in vivo maintenance, we have identified in preliminary screening 148 virulence-associated genes encoding 137 novel and 11 previously identified virulence factors (Potvin et al., 2003). As is the case for all highthroughput signature-tagged mutagenesis (STM) screenings, the challenge of mutants identified as defective in virulence lies in defining the function of the corresponding genes. In this study, we have characterized $P$. aeruginosa PycR encoded by PA5437 as a regulator of virulence factors in vivo. PycR belongs to the LTTR family and is essential for maintenance of $P$. aeruginosa in a rat model of chronic lung infection. Inactivation of $p y c R$ abolishes the expression of several virulence factors, including lipase, esterase and biofilm production.

\section{METHODS}

Bacterial strains, plasmids, primers, media and culture conditions. Bacterial strains and plasmids used in this study are listed in Table 1. Unless otherwise indicated, both Escherichia coli and $P$. aeruginosa were grown in tryptic soy broth (TSB) or Mueller-Hinton broth (MHB) (Difco). When needed, these media were supplemented with $1.5 \%$ bacto agar, gentamicin $\left(\mathrm{Gm} ; 50 \mu \mathrm{g} \mathrm{ml}^{-1}\right.$ for $\Delta p y c R:: \mathrm{Gm}^{\mathrm{R}}$ mutant and PAO1/pUCP19:: $\mathrm{Gm}^{\mathrm{R}}$, or $150 \mu \mathrm{g} \mathrm{m}^{-1}$ for P. aeruginosa exconjugants), ampicillin (Ap; $100 \mu \mathrm{g} \mathrm{ml}^{-1}$ for E. coli SM10), chloramphenicol $\left[\mathrm{Cm} ; 34 \mu \mathrm{g} \mathrm{ml}{ }^{-1}\right.$ for E. coli Tuner(DE3)pLacI], tetracycline (Tc; $10 \mu \mathrm{g} \mathrm{ml}^{-1}$ for E. coli $\mathrm{S} 17-1$ or $50 \mu \mathrm{g} \mathrm{ml}^{-1}$ for $P$. aeruginosa) (Sigma-Aldrich) or carbenicillin $\left[\mathrm{Cb} ; 50 \mu \mathrm{g} \mathrm{ml}^{-1}\right.$ for E. coli Tuner(DE3)pLacI or $500 \mu \mathrm{g} \mathrm{ml}^{-1}$ for $P$. aeruginosa] (Invitrogen). Primers used in this study are listed in Supplementary Table S1. Restriction enzymes, T4 DNA ligase, T4 DNA polymerase and T4 polynucleotide kinase were purchased from New England Biolabs and used in standard procedures (Sambrook \& Russell, 2001). HotStart Taq DNA polymerase was from Qiagen and the PCRs were performed in an iCycler (Bio-Rad).
Construction of the $\boldsymbol{P}$. aeruginosa mutant $\triangle p y c R$. For construction of deletion mutant $P$. aeruginosa $\triangle p y c R$, the sacB-based strategy described elsewhere was used (Hoang et al., 1998). Plasmid pMON3500 (pUCP19 containing the pycR ORF; see below for methods for complementation of the $\triangle p y c R$ mutation) was doubledigested with BbsI and BssHII to delete $430 \mathrm{bp}$ of $p y c R$ and gelpurified using a Perfectprep Gel Cleanup kit (Eppendorf Canada). Truncated pMON3500 was then blunted using 1.5 U T4 DNA polymerase, $0.1 \mathrm{mM}$ dNTPs, BSA and buffer as recommended by the manufacturer in a total volume of $20 \mu \mathrm{l}$, and was purified using Amicon-Microcon-PCR Filter Devices (Millipore). The DNA of the blunted $\mathrm{Gm}^{\mathrm{R}}$ selectable marker flanked by Flp recombinase target sites was then ligated into the truncated pMON3500 and introduced by electroporation into E. coli DH10B (Table 1). To obtain the insert from the vector pUCP19, double digestion with XmaI and SfiI was performed, and the insert (2038 bp) was gel-purified, blunted and purified using Microcon-PCR. A $2 \mathrm{~kb}$ truncated pMON3500 $+\mathrm{Gm}^{\mathrm{R}}$ was cloned into the SmaI site of pEX18Tc and transformed into E. coli S17-1 (Table 1). The recombinant plasmids were conjugated from E. coli S17-1 into PAO1 at $30{ }^{\circ} \mathrm{C}$ at a $10: 1$ recipient: donor ratio, and exconjugants were selected on Pseudomonas isolation agar (PIA; Difco) containing $150 \mu \mathrm{g} \mathrm{Gm} \mathrm{ml}^{-1}$. Merodiploids were resolved by plating on PIA medium containing $150 \mu \mathrm{g} \mathrm{Gm} \mathrm{ml}^{-1}$ and $5 \%$ sucrose. Deletion of the chromosomally integrated $\mathrm{Gm}^{\mathrm{R}}$ marker by Flp recombinase-catalysed excision was achieved by conjugal transfer of the Flp-expressing pFLP2 vector from E. coli SM10 (Table 1) into $P$. aeruginosa PAO $1 \Delta p y c R:: \mathrm{Gm}^{\mathrm{R}}$ at $30^{\circ} \mathrm{C}$. P. aeruginosa PAO1 $\Delta p y c R:: \mathrm{Gm}^{\mathrm{R}}$ and PAO1 $\Delta p y c R$ mutants were confirmed by performing colony PCR on several isolates using PA5437-XmaI and PA5437-SacI primers (Supplementary Table S1). Cell suspensions of PIA-grown sucrose ${ }^{\mathrm{R}}, \mathrm{Tc}^{\mathrm{S}}, \mathrm{Cb}^{\mathrm{S}}, \mathrm{Gm}^{\mathrm{R}}$ or $\mathrm{Tc}^{\mathrm{S}}, \mathrm{Cb}^{\mathrm{S}}, \mathrm{Gm}^{\mathrm{S}}$ cells were boiled for $5 \mathrm{~min}$, and lysates were then transferred to tubes containing PCR buffer (Qiagen), $200 \mu \mathrm{M}$ dNTPs and $10 \mathrm{pmol}$ of each primer with $2.5 \mathrm{U}$ HotStart Taq DNA polymerase (Qiagen). Touchdown PCR $\left(65-55^{\circ} \mathrm{C}\right)$ was performed. The PAO1 1 pycR:: $\mathrm{Gm}^{\mathrm{R}}$ mutant strain was then used for in vivo experiments and the $\Delta p y c R$ mutant strain for all other virulence experiments.

Complementation of $\boldsymbol{\Delta p} \boldsymbol{y} \boldsymbol{c} \boldsymbol{R}$ mutation. Plasmid pMON3500 (Table 1) was constructed using an XmaI-SacI fragment $(1.2 \mathrm{~kb})$ from $P$. aeruginosa $\mathrm{PAO} 1$ containing the ORF of the $p y c R$ gene amplified by PCR and cloned into the multiple cloning site of the shuttle vector pUCP19. Vector DNA was gel-purified. Amplification and restriction sites were introduced by PCR using $10 \mathrm{pmol}$ of two 30-mer oligonucleotides, PA5437-XmaI and PA5437-SacI (Supplementary Table S1), with $2.5 \mathrm{U}$ HotStart Taq DNA polymerase, $200 \mu \mathrm{M}$ dNTPs and buffer as recommended by the manufacturer, with genomic DNA of $P$. aeruginosa PAO1. Touchdown PCR (70$60{ }^{\circ} \mathrm{C}$ ) was performed as described above. PCR products were purified using Microcon-PCR. Plasmid pMON3500 (pUCP19 containing $p y c R$ ORF) was introduced by electroporation into $E$. coli DH10B (Table 1), confirmed by sequencing, and electroporated into $P$. aeruginosa $\triangle p y c R$ mutant.

Primer extension analysis. RNA was isolated from exponentially growing cells $\left(\mathrm{OD}_{600}=0.6\right)$ (Bowtell \& Sambrook, 2003) of $P$. aeruginosa strain PAO1 containing plasmid pMON3500 (pUCP19 containing $p y c R$ ORF). RNA was quantified using a Quant-IT RiboGreen RNA assay kit (Molecular Probes, Invitrogen). The primers used in extension experiments were PA5436-37_for and PA5436-37_rev (Supplementary Table S1), which correspond to nucleotides -4 to +10 and -4 to +14 relative to the PA5436 ( $p y c A)$ and $p y c R$ initiation codons, respectively. Primers were radioactively labelled using $\left[\gamma_{-}{ }^{32} \mathrm{P}\right] \mathrm{ATP}$ (Perkin-Elmer Life Sciences,). Primer extension reactions were carried out using $60 \mu \mathrm{g}$ RNA and the Primer Extension System-AMV Reverse Transcriptase kit (Promega). Primer extension reactions were electrophoresed on a sequencing gel 
Table 1. Bacterial strains and plasmids used in this work

\begin{tabular}{|c|c|c|}
\hline Strain or plasmid & Relevant characteristic(s) & Source or reference \\
\hline \multicolumn{3}{|l|}{ E. coli strains } \\
\hline ElectroMaxDH10B & Electrocompetent cells & Invitrogen \\
\hline S17-1 ( $\lambda$ pir $)$ & $\mathrm{Tp}^{\mathrm{R}}, \mathrm{Sm}^{\mathrm{R}}, R P 4-2-T c:: M u-K m:: \mathrm{Tn} 7$, recA deletion of E. coli 294 & Simon et al. (1983) \\
\hline SM10 & $\mathrm{Ap}^{\mathrm{R}}$, thi-1 thr leu tonA lacY supE recA:: RP4-2-Tc:: $\mathrm{Mu}$ & Hoang et al. (1998) \\
\hline Tuner(DE3)pLacI & $\mathrm{Cm}^{\mathrm{R}}$, lacZY deletion mutant of $\mathrm{BL} 21$ & Novagen \\
\hline \multicolumn{3}{|l|}{$P$. aeruginosa strains } \\
\hline PAO1 & PAO1293, Cm ${ }^{\mathrm{S}}$, E79 tv-2, wild-type, derivative of prototrophic PAO1 & Holloway et al. (1979) \\
\hline STM5437 & PAO1 STM5437:: miniTn5 mutant inactivating PA5437 gene & Potvin et al. (2003) \\
\hline PABS1 & PAO1 $\Delta l i p A-\Delta l i p H$, mutant defective in lipase & Wilhelm et al. (1999) \\
\hline PASCH1 & $\mathrm{PAO} 1 \Delta e s t A$, mutant defective in esterase & Wilhelm et al. (1999) \\
\hline $\mathrm{PAO} 1 \Delta p y c R$ & $\begin{array}{l}\text { PAO1293 } \Delta p y c R \text { mutant, } 960 \mathrm{bp} \text { fragment with internal deletion of PA5437 } \\
(p y c R) \text { gene }\end{array}$ & This study \\
\hline $\mathrm{PAO} 1 \Delta p y c R:: \mathrm{Gm}^{\mathrm{R}}$ & $\begin{array}{l}\text { PAO1293 } \Delta p y c R:: \mathrm{Gm}^{\mathrm{R}}, \mathrm{Gm}^{\mathrm{R}}, 430 \text { bp replacement of PA5437 }(p y c R) \text { gene } \\
\text { with } \mathrm{Gm}^{\mathrm{R}} \text { cassette }\end{array}$ & This study \\
\hline PA14 & Wild-type prototrophic laboratory strain & Holloway et al. (1979) \\
\hline PA14sad-36 & PA14sad-36 (flgK) ::Tn5B30, Tc ${ }^{\mathrm{R}}$, biofilm mutant & $\begin{array}{l}\text { O’Toole \& Kolter } \\
\text { (1998b) }\end{array}$ \\
\hline \multicolumn{3}{|l|}{ Plasmids } \\
\hline pUCP19 & $\mathrm{Cb}^{\mathrm{R}}$, cloning vector & West et al. (1994) \\
\hline pUCP19:: $\mathrm{Gm}^{\mathrm{R}}$ & $\begin{array}{l}\mathrm{Gm}^{\mathrm{R}}, 743 \mathrm{bp} \text { SspI/BsaI fragment of bla gene of pUCP19 cloning vector replaced } \\
\text { with } 956 \mathrm{bp} \text { XbaI fragment of } \mathrm{Gm}^{\mathrm{R}} \text { selectable marker lacking FLP recombinase } \\
\text { target (FRT) sites }\end{array}$ & This study \\
\hline pMON3500 & $\mathrm{Cb}^{\mathrm{R}}, \mathrm{PA} 5437(p y c R)$ gene in pUCP19 vector & This study \\
\hline pEX18Tc & $\begin{array}{l}\mathrm{Tc}^{\mathrm{R}} \text {, ori } T^{+} s a c B^{+} \text {, gene replacement vector with multiple cloning site (MCS) } \\
\text { from pUC18 }\end{array}$ & Hoang et al. (1998) \\
\hline pFLP2 & $\begin{array}{l}\mathrm{Ap}^{\mathrm{R}}, 2.6 \mathrm{~kb} \text { BamHI/SphI fragment from pALB2 ligated between the same sites } \\
\text { of pPS908 }\end{array}$ & Hoang et al. (1998) \\
\hline pETBlue-2 & $\mathrm{Cb}^{\mathrm{R}}, \mathrm{R} 6 \mathrm{~K}-$ based suicide delivery plasmid & Novagen \\
\hline pMON3501 & $\mathrm{Cb}^{\mathrm{R}}, \mathrm{PA} 5437(p y c R)$ gene in pETBlue-2 vector & This study \\
\hline
\end{tabular}

along with DNA sequencing reactions performed with the same primers that were used for the primer extension reactions. Sequencing reactions were completed using a Sequenase PCR Product Sequencing kit (USB).

Cloning and overproduction of PycR protein. For construction of the C-terminal His-tagged PycR expression vector pMON3501, the $p y c R$ gene was amplified from $P$. aeruginosa PAO1 genomic DNA by PCR. The primers were 38-mer oligonucleotide PA5437_NcoI and 30mer oligonucleotide PA5437_XhoI (Supplementary Table S1) and 70$60{ }^{\circ} \mathrm{C}$ Touchdown PCR was performed as described above. The resulting PCR product was digested with $\mathrm{NcoI}$ and XhoI, purified using Microcon-PCR and cloned into the multiple cloning site of expression vector pETBlue-2 (Novagen). Plasmid pMON3501 (pETBlue-2 containing $p y c R$ ORF) was introduced by electroporation into E. coli $\mathrm{DH} 10 \mathrm{~B}$ (Table 1), and the integrity of the $p y c R$ gene was confirmed by sequencing.

For PycR overexpression, clones of E. coli Tuner(DE3)pLacI (Novagen) carrying pMON3501 were grown at $37{ }^{\circ} \mathrm{C}$ with shaking in LB broth (EMD Chemicals) containing $50 \mu \mathrm{g} \mathrm{Cb} \mathrm{ml}^{-1}$ and $34 \mu \mathrm{g} \mathrm{Cm} \mathrm{ml}^{-1}$. At $\mathrm{OD}_{600} 0.5$, the culture was induced with $0.01 \mathrm{mM}$ IPTG and incubated overnight at $32{ }^{\circ} \mathrm{C}$ with shaking, after which cells were harvested by centrifugation and resuspended in $4 \mathrm{ml} \mathrm{PycR}$ buffer $(20 \mathrm{mM}$ Tris/ $\mathrm{HCl}$, pH 8.0, $1 \mathrm{mM}$ EDTA, $10 \mathrm{mM} \mathrm{NaCl}, 0.1 \mathrm{mM}$ DTT) containing $1 \mathrm{mg}$ lysosyme $\mathrm{ml}^{-1}$ (Sigma-Aldrich) and protease inhibitor cocktail tablets (Complete Mini, EDTA-free, Roche Diagnostics). Cells were broken at $4{ }^{\circ} \mathrm{C}$ by sonication, and insoluble material was removed by centrifugation at $4{ }^{\circ} \mathrm{C}$ for $30 \mathrm{~min}$ at 17000 r.p.m. The identity of the
PycR protein was confirmed by Western blotting using anti-His-tag antibody and by MALDI-TOF MS.

Electrophoretic mobility shift assay (EMSA). The EMSA was based on a protocol of Schuster et al. (2004). A specific DNA probe of $\sim 241$ bp was generated by PCR amplification of the intergenic region between $p y c A$ and the $p y c R$ genes using the PA5436-37_for and PA5436-37_rev primers (Supplementary Table S1). A non-specific DNA probe was generated by PCR amplification of $\sim 177 \mathrm{bp}$ of the pycR-coding region using the PA5437_cod_for and PA5437_cod_rev primers (Supplementary Table S1). The resulting PCR products were labelled using $\left[\gamma-{ }^{32} \mathrm{P}\right] \mathrm{ATP}$ (Perkin-Elmer) and T4 polynucleotide kinase. Binding reactions contained 100 pmol of each specific and non-specific DNA in a final volume of $20 \mu \mathrm{l}$ DNA-binding buffer [20 mM Tris- $\mathrm{HCl}, \mathrm{pH}$ 8.0, $50 \mathrm{mM} \mathrm{KCl,} 1 \mathrm{mM}$ EDTA, $1 \mathrm{mM}$ DTT, $100 \mu \mathrm{g} \mathrm{BSA} \mathrm{ml}^{-1}, 10 \mu \mathrm{g}$ poly$(\mathrm{dIdC}) \mathrm{ml}^{-1}, 5 \%(\mathrm{v} / \mathrm{v})$ glycerol]. Cell extracts of E. coli Tuner(DE3)pLacI harbouring pETBlue-2 alone or pMON3501 (pETBlue-2 containing the $p y c R$ ORF), before and after IPTG induction, were added at the indicated concentrations and the reaction mixtures were incubated at room temperature for $30 \mathrm{~min}$. The unlabelled specific DNA was used at the indicated concentrations as a specific competitor. Loading dye [250 mM Tris- $\mathrm{HCl}, \mathrm{pH} 7.5$, $0.2 \%(\mathrm{w} / \mathrm{v})$ bromophenol blue, $40 \%(\mathrm{v} / \mathrm{v})$ glycerol] was added to control reactions only, and the reaction mixtures were electrophoresed on native $5 \%$ Tris-borate-EDTA (TBE) polyacrylamide gels ( $1: 30$ bis-acrylamide to acrylamide ratio) in $0.5 \times$ TBE buffer at $150 \mathrm{~V}$ for $1-2 \mathrm{~h}$ at room temperature. The gel was subsequently dried, and radiolabelled protein-DNA complexes were detected using PhosphorImager technology. 
Preparation of agarose bead-embedded bacteria for in vivo experiments. The preparation protocol for $P$. aeruginosa wild-type/ mutant bacterial mixture in agarose beads was modified from that of van Heeckeren \& Schluchter (2002). PAO1 wild-type containing plasmid pUCP19 or pUCP19:: $\mathrm{Gm}^{\mathrm{R}}$ (Table1), the $\triangle p y c R:: \mathrm{Gm}^{\mathrm{R}}$ mutant and the complemented $\triangle p y c R$ mutant were grown separately in TSB. After overnight incubation in a shaking incubator at $37^{\circ} \mathrm{C}$, the $\mathrm{OD}_{600}$ of each culture was noted. A $100 \mu \mathrm{l}$ aliquot of each overnight culture was diluted to $10 \mathrm{ml}$ with fresh TSB to give a final concentration of $\sim 1 \times 10^{9}$ c.f.u. $\mathrm{ml}^{-1}$. A $250 \mu \mathrm{l}$ aliquot of the wildtype was mixed with $250 \mu \mathrm{l}$ of the mutant and added to $4.5 \mathrm{ml} \mathrm{TSB}$. A $200 \mathrm{ml}$ volume of sterile mineral oil was equilibrated at $48{ }^{\circ} \mathrm{C}$ and vigorously agitated in a water bath. A $20 \mathrm{ml}$ volume of $2 \%$ lowmelting-temperature agarose (NuSieve, FMC BioProduct) in PBS was also prewarmed at $48{ }^{\circ} \mathrm{C}$ and rapidly mixed with a $5 \mathrm{ml}$ final volume of an equal ratio of wild-type and mutant mixture and added to the mineral oil. The final cell concentration was estimated to be $\sim 1 \times 10^{6}$ c.f.u. $\mathrm{ml}^{-1}$, and at the end of the preparation we expected an approximate bacterial loss of 2 logs. The mixture was cooled gradually for $5 \mathrm{~min}$ with ice chips. The agarose beads were washed with $200 \mathrm{ml}$ $0.5 \%$ deoxycholic acid sodium salt (SDC, Sigma-Aldrich) in PBS, once with $0.25 \%$ SDC/PBS and three times with PBS in a $500 \mathrm{ml}$ Squibb-type separator funnel. The bead slurry was allowed to settle for a few minutes at $4{ }^{\circ} \mathrm{C}$ and the remaining PBS was removed. The agarose beads were then homogenized for $30 \mathrm{~s}$ with a polytron homogenizer (Kinematica, model PTA 20S, Dispergier und Mischtechnik) and serially diluted. Dilutions were plated in triplicate on Mueller-Hinton agar (MHA) plates with appropriate antibiotics $\left(500 \mu \mathrm{g} \mathrm{Cb} \mathrm{ml}^{-1}\right.$ for wild-type PAO1/pUCP19 or complemented $\Delta p y c R$ mutant selection, and $50 \mu \mathrm{g} \mathrm{Gm} \mathrm{m}^{-1}$ for $\Delta p y c R: \mathrm{Gm}^{\mathrm{R}}$ mutant or wild-type PAO1/pUCP19:: $\mathrm{Gm}^{\mathrm{R}}$ selection).

In vivo and in vitro competitive index $(\mathbf{C l})$. We have used the rat chronic lung infection model to determine the in vivo CI of $\Delta p y c R: \mathrm{Gm}^{\mathrm{R}}$ and the complemented $\Delta p y c R$ mutant strains. Male Sprague-Dawley rats, $450-500 \mathrm{~g}$ in weight, were used in accordance with the rules of the ethics committee for animal treatment. The animals were anaesthetized using isofluorane and inoculated by intubation with $120 \mu \mathrm{l}$ of a suspension of agar beads containing $10^{4}$ c.f.u. wild-type/mutant bacterial mixture. After 7 days, lungs were removed from sacrificed rats, and homogenized tissues were plated in triplicate on PIA for assay of the total number of $P$. aeruginosa bacterial cells and on MHA supplemented with $500 \mu \mathrm{g} \mathrm{Cb} \mathrm{ml}^{-1}$ or $50 \mu \mathrm{g} \mathrm{Gm} \mathrm{ml}^{-1}$. In conjunction with each in vivo competition, an in vitro competition of $\triangle p y c R:: \mathrm{Gm}^{\mathrm{R}}$ and complemented mutant was carried out with the same bacterial ratios. First, the bacterial mixtures were stored overnight at $4{ }^{\circ} \mathrm{C}$ in $25 \mathrm{ml} \mathrm{TSB}$ and then grown to lateexponential phase at $37{ }^{\circ} \mathrm{C}$ with shaking. Competitive indexes (CIs) were calculated as the ratio of mutant to wild-type bacteria recovered in vivo (or from in vitro bacterial mixtures) adjusted by the input ratio. The final CI data were represented as the geometric mean for animals in the same group. Each in vivo and in vitro competition was tested for statistical significance by Student's two-tailed $t$ test.

Lipase and esterase assays. Bacteria were grown aerobically in glass tubes in $2 \mathrm{ml} \mathrm{LB}$ broth in the presence of $1 \mathrm{mM}$ IPTG at $37{ }^{\circ} \mathrm{C}$ for $48 \mathrm{~h}$, and $1 \mathrm{ml}$ of cell culture was centrifuged for $5 \mathrm{~min}$ at maximum speed. Lipase and esterase extracellular activities for wildtype PAO1, the $\triangle p y c R$ mutant and, as respective controls, the PABS1 lipase-defective mutant and the PASCH1 esterase-defective mutant (Table 1) were determined from cell-free culture supernatants. For the lipase quantitative assay, $30 \mathrm{mg} p$-nitrophenyl palmitate ( $p$ NPP; Sigma-Aldrich) was dissolved in $10 \mathrm{ml}$ 2-propanol and added to $90 \mathrm{ml}$ Sørensen phosphate buffer (17 parts $63 \mathrm{mM} \mathrm{Na}_{2} \mathrm{HPO}_{4}$ to one part $5 \mathrm{mM} \mathrm{KH}_{2} \mathrm{PO}_{4}$; $\mathrm{pH}$ 8.0) (K. E. Jaeger, personal communication) supplemented with $207 \mathrm{mg}$ sodium deoxycholate and $100 \mathrm{mg}$ gum arabic, yielding a final $p$ NPP concentration of $1 \mathrm{mM}$. For the esterase assay, $2.15 \mu \mathrm{l} 1 \mathrm{mg} p$-nitrophenyl caproate $\mathrm{ml}^{-1}$ ( $p \mathrm{NPC}=n$-hexanoic acid 4-nitrophenyl ester; ABCR) was dissolved in ethanol $(5 \mathrm{ml})$, and added to tubes with $9.5 \mathrm{ml} 100 \mathrm{mM}$ potassium phosphate buffer ( $\mathrm{pH} 7.0$ ) containing $10 \mathrm{mM} \mathrm{MgSO}_{4}$ to yield a final concentration of $0.1 \mathrm{mM}$ pNPC. For both assays, samples $(80 \mu \mathrm{l})$ were added to the substrate solution to give a final volume of $1 \mathrm{ml}$, and the $\Delta \mathrm{OD}_{410} \mathrm{~min}^{-1}$ was recorded for $5-15 \mathrm{~min}$ at $37^{\circ} \mathrm{C}$ for lipase and at room temperature for esterase with a Cary spectrophotometer (Varian). The relative enzyme activities were determined as the ratio $\mathrm{OD}_{410}$ (enzyme activity) to $\mathrm{OD}_{600}$ (cell density).

Biofilm formation assay. To assess and quantify the formation of biofilm in the two wild-type strains PAO1 and PA14 and in PAO1 $\Delta p y c R$, complemented $\Delta p y c R$ mutant and PA14sad-36 mutant, a 96-well-plate rapid biofilm formation assay was performed as described elsewhere (O’Toole \& Kolter, 1998a). All strains were grown in the presence of $1 \mathrm{mM}$ IPTG in overnight LB cultures.

Sampling, RNA extraction and transcriptional profiling. For GeneChip analysis, $P$. aeruginosa $\mathrm{PAO} 1$ wild-type and $\Delta p y c R$ mutant were grown in TSB broth at $37{ }^{\circ} \mathrm{C}$ with shaking. Samples $(10 \mathrm{ml})$ of cells from early exponential phase cultures $\left(\mathrm{OD}_{600}=0.4\right)$ were collected, and RNA degradation was minimized by adding $1.25 \mathrm{ml}$ ice-cold $5 \%(\mathrm{v} / \mathrm{v})$ phenol in absolute ethanol $(\mathrm{pH}<7.0)$. RNA was extracted and purified using a standard procedure (Bowtell \& Sambrook, 2003). DNA contamination of purified RNA was monitored using PCR for amplification of the $r p l U$ gene with the primers rplU_for and rplU_rev (Supplementary Table S1). RNA integrity was monitored by agarose gel electrophoresis of glyoxylated samples. Preparation of labelled cDNA and processing of the $P$. aeruginosa GeneChip arrays was performed as described elsewhere (Schuster et al., 2003). Washing, staining, and scanning of the GeneChips were performed by the University of Iowa DNA Core Facility using an Affymetrix fluidics station. GeneChip data after two repeats were analysed using GeneChip Operating Software (Affymetrix). Analysis of all results was performed using the $P$. aeruginosa Genome Project database website (www.pseudomonas. com), protein-protein BLAST (BLASTP) and the conserved domain architecture retrieval tool (CDART) on the NCBI server (http:// www.ncbi.nlm.nih.gov/).

Isolation of total RNA, synthesis of CDNA and RT-PCR analysis. In order to validate the results obtained by GeneChip analysis, seven differentially expressed genes were also tested by quantitative realtime PCR (qRT-PCR) with total RNA. P. aeruginosa PAO1 wild-type and $\Delta p y c R$ mutant were prepared in the same way as described for transcriptional profiling. Total RNA extraction was performed using the TRIzol method (Invitrogen) according to the instructions of the supplier; then the RNA cleanup was done using an RNeasy Mini kit (Qiagen). cDNA was generated from $1 \mu \mathrm{g}$ total RNA using a random primer hexamer (100 ng $\mu \mathrm{l}^{-1}$, Invitrogen) and a QuantiTec Reverse Transcription kit with integrated removal of genomic DNA contamination (Qiagen) following the instructions provided by the manufacturer. The cDNA mixture was diluted $1: 10$ in water prior to real-time PCR quantification. A cDNA equivalent to $10 \mathrm{ng}$ total RNA was used per $15 \mu \mathrm{l}$ PCR reaction. Amplifications were performed in $1 \times$ Quantitect SYBR Green mixture (Qiagen) with $0.3 \mu \mathrm{M} 5^{\prime}$ and 3' primers. Primer design was performed with Primer3 (Rozen \& Skaletsky, 2000), available at http://biotools.umassmed.edu/bioapps/ primer3_www.cgi, and primers are listed in Supplementary Table S1 (from PA0171-for to PA5436-rev). All primers had a melting temperature $\left(T_{\mathrm{m}}\right)$ between 62 and $67{ }^{\circ} \mathrm{C}$, and all amplicon sizes were between 100 and $250 \mathrm{bp}$. Amplifications were carried out in a LightCycler 480 (Roche Diagnostics). After an initial $15 \mathrm{~min}$ activation step at $95{ }^{\circ} \mathrm{C}, 45$ cycles $\left(94{ }^{\circ} \mathrm{C}\right.$ for $10 \mathrm{~s}, 62{ }^{\circ} \mathrm{C}$ for $2 \mathrm{~min}$ ) were performed, and a single fluorescent reading was obtained after each cycle immediately following the annealing/elongation step at 
$62{ }^{\circ} \mathrm{C}$. A melting curve was performed at the end of cycling to ensure that there was single amplification. Crossing point $(\mathrm{Cp})$ values were determined with the software supplied with the instrument. Standard curves were used to transform $\mathrm{Cp}$ values obtained from total RNA samples into transcript number. Samples were normalized to the reference gene rpsL (PA4268).

Phenotype MicroArray analysis. To assess the overall effect of PycR transcriptional regulation on cell metabolism, phenotype analyses were carried out in triplicate using Phenotype MicroArrays (PMs) (Biolog) which measure carbon (C) (PM1-2), nitrogen (N) (PM3) and phosphorus (P)/sulfur (S) (PM4) metabolism. This technique involves the deduction of cellular phenotypes using cell respiration as the reporter system. Before inoculation into the PM1, PM2, PM3 and PM4 96-well microplates, PAO1 wild-type and $\Delta p y c R$ mutant were grown overnight at $37{ }^{\circ} \mathrm{C}$ on plates containing the nutrient-limited medium R2A agar. Cells were picked up from the surface of the R2A plates using a sterile cotton swab and were resuspended in IF-0 (inoculating fluid) supplemented with menadione sodium bisulfite $\left(5.524 \mu \mathrm{g} \mathrm{ml}^{-1}\right)$ for PM1-2 and with menadione sodium bisulfite $\left(5.524 \mu \mathrm{g} \mathrm{ml}^{-1}\right)$, sodium succinate $\left(5.402 \mu \mathrm{g} \mathrm{ml}^{-1}\right)$ and ferric citrate $\left(0.49 \mu \mathrm{g} \mathrm{ml}^{-1}\right)$ for PM3-4 at a density corresponding to $85 \%$ transmittance in the Biolog turbidimeter using $20 \mathrm{~mm}$ diameter tubes. The suspensions were then inoculated into the appropriate microplate at a volume of $100 \mu \mathrm{l}$ per well. The microplates were placed at $37{ }^{\circ} \mathrm{C}$ for either $24 \mathrm{~h}$ (PM1-2) or $48 \mathrm{~h}$ (PM3-4), at which time sufficient purple colour had developed in the positive control wells, while the negative control wells remained colourless. The microplates were then examined for utilization of the C, N, P or S source in a particular well.

Statistical analysis. Statistical analyses were performed with GraphPad Prism 5 software using the unpaired $t$ test or the MannWhitney sum test.

\section{RESULTS}

\section{Identification of the $P$. aeruginosa STM5437 mutant}

Novel pathogenicity genes important for infection of $P$. aeruginosa had been identified previously using PCR-based STM (PCR-STM) (Lehoux et al., 2002, 2004). A collection of 7968 STM mutants was screened in a rat model of chronic lung infection (Cash et al., 1979). A total of 214 mutants, representing transposition events into $148 \mathrm{ORFs}$, were shown to be attenuated in lung infection and were retained for further analysis (Potvin et al., 2003). The STM5437 mutant inactivating the PA5437 gene was shown to be attenuated in a pool of 72 STM mutants when screened in a rat lung model of chronic infection. These studies indicated a possible attenuation for the STM5437 mutant, which was chosen for detailed analysis.

\section{Analysis of the PA5437 (pycR) gene}

The PA5437 gene, now called $p y c R$, for putative pyruvate carboxylase regulator, was identified by bioinformatics analysis as a putative transcriptional regulator, which codes for a 311 aa protein of $\sim 34.6 \mathrm{kDa}$. According to www.pseudomonas.com, the P. aeruginosa PycR had $44 \%$ identity with CbbRI of Rhodobacter capsulatus, a LysR family transcriptional regulator of the $\mathrm{CO}_{2}$-binding operons. The structural organization of $p y c R$ and the divergently transcribed PA5436-5435 ( $p y c A B)$ operon is shown in Fig. 1. $p y c R$ has signature motifs of a helix-turnhelix DNA binding region, and LysR motifs were predicted with sequences from www.pseudomonas.com using BLASTP and CDART software from the NCBI server (http:// www.ncbi.nlm.nih.gov/).

Frequently, LTTRs are divergently transcribed from their target genes (Schell, 1993). As depicted in Fig. 1, P. aeruginosa $p y c A B$, encoding pyruvate carboxylase subunits (Lai et al., 2006), are divergently transcribed from $p y c R$, suggesting that $p y c R$ controls their expression.

\section{Construction of PAO1 1 pycR mutant and complementation of the $\triangle p y c R$ mutation}

In order to eliminate possible polar effects due to insertional inactivation by mini- $\operatorname{Tn} 5$ and to obtain a clean genetic background for all in vivo and in vitro experiments, the PAO1 $\Delta p y c R$ deletion mutant was constructed by allelic replacement (Hoang et al., 1998). The $\Delta p y c R$ deletion was confirmed by PCR (data not shown). For complementation analysis, an XmaI-SacI $1.2 \mathrm{~kb}$ genomic DNA fragment containing the complete $p y c R$ gene was cloned into the expression vector pUCP19 (see Methods) and transformed into the PAO1 $\Delta p y c R$ mutant strain.

\section{In vivo importance of $P$. aeruginosa PycR in chronic lung infection}

Since the STM5437 mutant was identified as being attenuated in vivo in combination with 72 other STM mutants in the pool, we further confirmed the in vivo defect of the $\triangle p y c R$ mutant in competition with the wild-type strain PAO1. The PAO1 $\Delta p y c R$ mutant and complemented strain were tested in rat lungs for 7 days to estimate in vivo maintenance in comparison with the wild-type strain. As depicted in Fig. 2, a mutation in $p y c R$ caused a severe defect

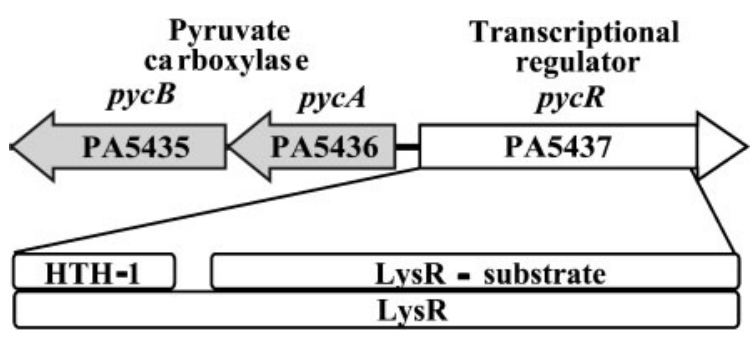

Fig. 1. Genomic organization of the PA5436-5435 (pycAB) operon and the PA5437 (pycR) gene. The $p y c A$ and $p y c B$ genes encode two subunits of pyruvate carboxylase. The $p y c R$ gene encodes a transcriptional regulator of $311 \mathrm{aa}$, and motifs such as the helix-turn-helix DNA binding region and LysR motifs were identified by bioinformatics analysis. The arrows indicate the direction of transcription. 


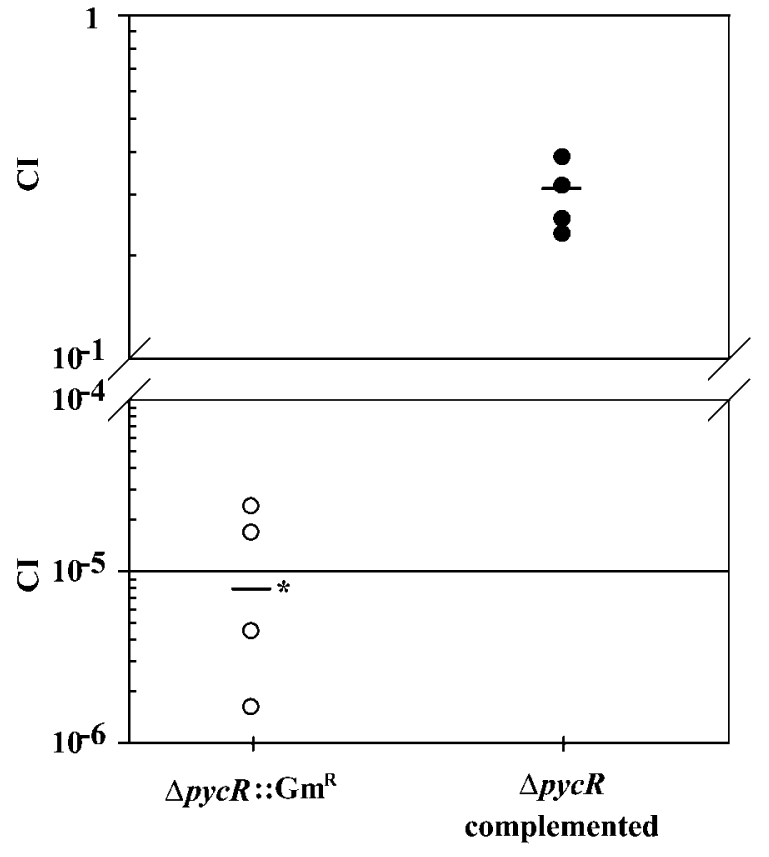

Fig. 2. In vivo $\mathrm{Cl}$ of $P$. aeruginosa $\triangle p y c R:: \mathrm{Gm}^{\mathrm{R}}$ and complemented $\triangle p y c R$ mutant after 7 days in the rat lung in competition with the wild-type PAO1 strain. Each circle represents the $\mathrm{Cl}$ for a single animal in each group. $\mathrm{A} \mathrm{Cl}$ of less then 1 indicates a virulence defect. Open circles indicate that no mutant was recovered from the animal, and 1 was substituted in the numerator when calculating the $\mathrm{Cl}$. The geometric mean of the Cls for all rats is shown as a solid line and statistically significant values are indicated with an asterisk ( ${ }^{\star} P=0.0001$, Mann-Whitney sum test). The in vitro $\mathrm{Cls}$ were 2.96 for $\Delta p y c R:: \mathrm{Gm}^{\mathrm{R}}$ and 0.97 for the complemented $\triangle p y c R$ mutant.

in growth and maintenance in vivo. The PAO1 $\Delta p y c R$ mutant strain gave a significant 100000 -fold decrease in c.f.u. in rat lung tissues. We noted that four animals had no bacteria 7 days post-infection. In contrast, the complemented mutant strain could be maintained, although growth was not completely restored to the level of the wild-type PAO1 strain. The partial in vivo complementation was expected because $p y c R$ gene expression of the complemented strain is under the control of the E. coli lac promoter present on the plasmid vector, which could not be induced in vivo.

Furthermore, we confirmed that $\Delta p y c R$ and the complemented mutant strain grew at the same rate as the wildtype PAO1 by using an in vitro CI. In comparison with the wild-type strain PAO1, the average in vitro CIs for $\mathrm{PAO} 1 \Delta p y c R$ and for the complemented mutant strain were 2.96 and 0.97 , respectively.

\section{Characterization of the $P$. aeruginosa $\Delta p y c R$ mutant}

Partial growth deficiency of the $P$. aeruginosa $\Delta p y c R$ mutant in glucose minimal medium. We noted a growth lag for the STM5437 mutant in minimal M9 (Gibco, BRL) medium supplemented with $0.4 \%$ glucose, $2 \mathrm{mM} \mathrm{MgSO}$ and $0.1 \mathrm{mM} \mathrm{CaCl}$. To eliminate the possibility of auxotrophy, we compared the growth in minimal liquid media (M9) of $P$. aeruginosa STM5437, the STM5437 complemented strain, and the $\triangle p y c R$ and the complemented $\triangle p y c R$ strains with the growth of the wild-type strain PAO1 (data not shown). A slight delay in growth was observed for the $\Delta p y c R$ (and STM5437) mutant at the beginning of the exponential phase. However, the mutant caught up with the wild-type after $6 \mathrm{~h}$, and at $24 \mathrm{~h}$, the numbers of c.f.u. were similar to that of the wild-type strain. $P$. aeruginosa $\Delta p y c R$ (and STM5437) complemented in trans grew like the wild-type PAO1 strain. The growth of all strains tested was similar on TSA or LB media (data not shown).

Reduced lipolytic activity of $P$. aeruginosa $\Delta p y c R$ mutant. Following the confirmation of the reduced in vivo virulence of the $\triangle p y c R$ mutant, several in vitro phenotypes known to be important for virulence were also examined. We tested $\mathrm{H}_{2} \mathrm{O}_{2}$ sensitivity, heat shock, proteolytic activity and bacterial motility of the $\Delta p y c R$ mutant. These phenotypes were found to be similar to those of the wild-type strain. In contrast, the lipolytic activities of $P$. aeruginosa $\Delta p y c R$ were altered. For both lipase (Fig. 3a) and esterase (Fig. 3b), the $\Delta p y c R$ mutant showed significantly reduced activities. Complementation of the $\Delta p y c R$ mutant restored the wild-type phenotype in both assays, confirming the efficacy of PycR expression when inducer is used. These results suggested that PycR potentially modulates these lipolytic activities. Phospholipase $\mathrm{C}$ production was slightly, but not significantly, lower for the $\triangle p y c R$ mutant strain when compared with the wild-type PAO1 (data not shown).

Influence of the $\Delta p y c R$ mutation on biofilm formation. Since the $P$. aeruginosa $\triangle p y c R$ mutant showed reduced virulence in the lung infection model and since biofilm formation is crucial for bacterial maintenance, we tested in vitro biofilm formation. The $\triangle p y c R$ mutant and the complemented strain were tested for their ability to form a biofilm on an abiotic surface in polyvinylchloride (PVC) microtitre dishes, and compared with the wild-type strain PAO1. Bacteria were grown in the wells in minimal M63 medium supplemented with glucose $(0.2 \%), \mathrm{MgSO}_{4}$ $(1 \mathrm{mM})$ and casamino acids (CAA; 0.5\%) (O'Toole \& Kolter, 1998b). The surface attachment-defective PA14sad36 mutant was used as a negative control. The growth rate in minimal medium after $6 \mathrm{~h}$ of incubation was the same for all strains tested (data not shown). The PAO1 $\Delta p y c R$ mutant was defective for biofilm formation since the crystal violet-stained ring formed on walls of PVC wells was smaller when compared with the wild-type strain (data not shown). Quantification of biofilm shown in Fig. 3(c) indicated that the number of biofilm-forming cells was significantly lower for the PAO1 $\Delta p y c R$ mutant in comparison with wild-type PAO1. In contrast, the 

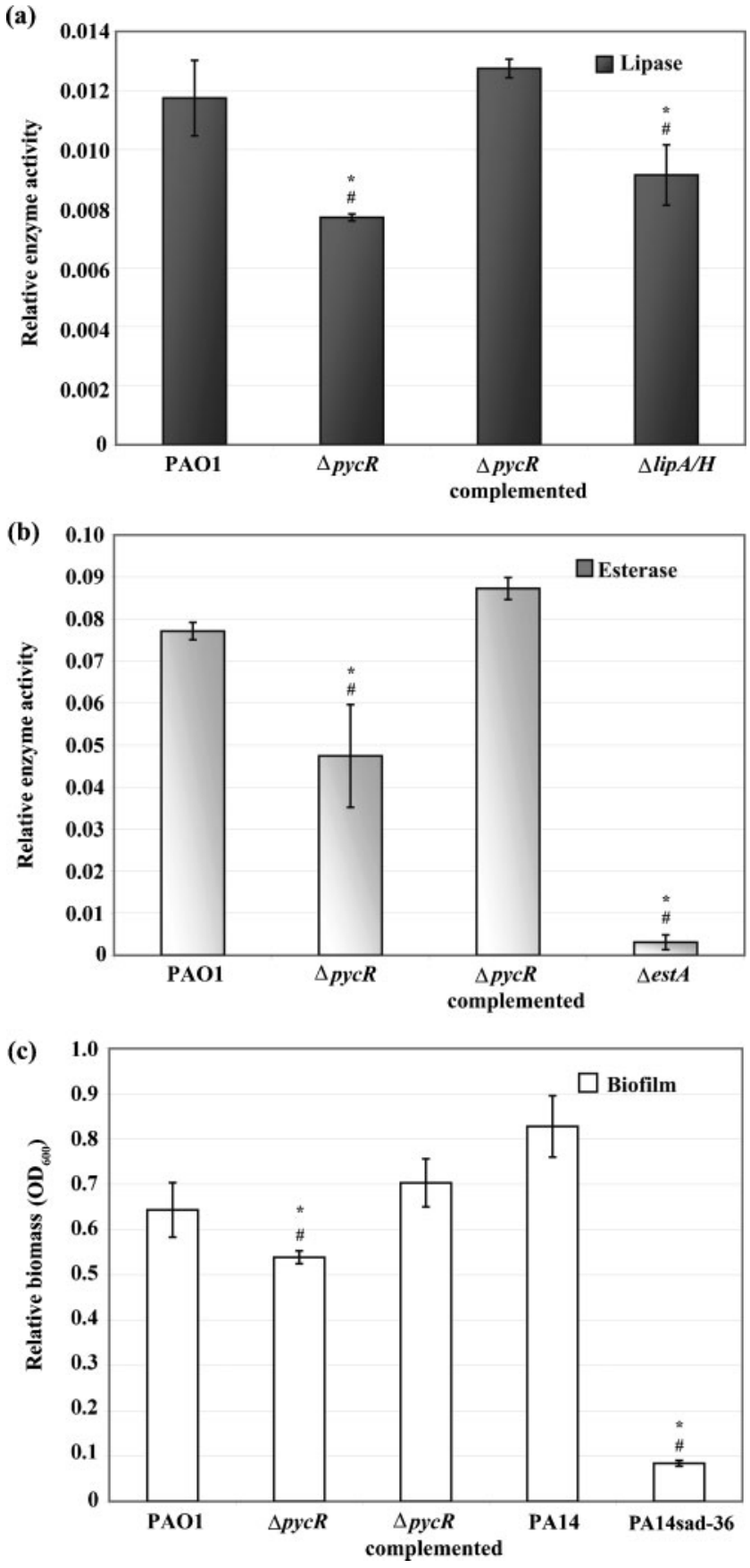

Fig. 3. Phenotypic characterization of the $\Delta p y c R$ mutant. Lipolytic activities of $P$. aeruginosa wild-type PAO1, $\triangle p y c R$, complemented $\triangle p y c R$ mutant, lipase-negative mutant $\Delta / i p A / H$ and esterase-negative $\triangle$ est $A$ mutant. Relative lipolytic activities of cell-free culture supernatants in liquid assays were determined as the ratio of $O D_{410}$ to $O D_{600}$ per $\mathrm{ml}$ culture. Lipase (a) and esterase (b) activities were assayed with $p$-nitrophenyl palmitate and $p$-nitrophenyl caproate, respectively. (c) Quantification of biofilm formation for $P$. aeruginosa wild-type PAO1, $\mathrm{PAO} 1 \Delta$ pycR mutant, complemented PAO1 $\Delta p y c R$ mutant and wildtype PA14 and PA14sad-36 mutant. Statistically significant values obtained with the unpaired $t$ test $(P \leqslant 0.05)$ are indicated with asterisks for comparisons with the wild-type (PAO1 or PA14), and with \# for comparisons with the complemented $\Delta p y c R$ mutant. complemented $\triangle p y c R$ mutant restored biofilm production to the level of the wild-type PAO1 strain in the presence of inducer.

\section{Analysis of the divergently transcribed operon pycAB}

Identification of the transcriptional start site of $p y c A$ and pyc $\boldsymbol{R}$ genes. To identify the transcriptional mRNA start site for $p y c R$ (PA5437) and for the divergently transcribed $p y c A B$ (PA5436-PA5435) operon, a primer extension analysis was done using total RNA extracted from the $P$. aeruginosa strain PAO1 containing pMON3500 (see Methods). Fig. 4 ( $a, b)$ shows that the extended products mapped at nucleotide positions -88 and -127 upstream of the GTG/ATG initiation codons of the $p y c A$ and $p y c R$ genes, respectively. The $p y c A-10$ (ATCCCA) and -35 (AACAAT) and $p y c R-10$ (TCGAGG) and -35 (TATAAG) sequences are indicated by boxes in Fig. 4(c). In both cases, the sequences showed three mismatches for -10 and two and one mismatches, respectively, for -35 (mismatches indicated in bold type) in comparison with the E. coli sigma 70 consensus - 10 (TTGACA) and -35 (TATAAT) (deHaseth et al., 1998).

LTTRs generally bind to inverted nucleotide repeats containing a T- $\mathrm{N}_{11}$-A motif in the core sequence (Schell, 1993). An examination of the sequence upstream of the pycR transcriptional start site revealed three typical LysR motifs (Fig. 4c), adjacent to its $-10 /-35$ region. The second PycR motif (indicated by bold italic type in Fig. 4c) had a perfect inverted repeat (CTGC-N $\mathrm{N}_{7}-\mathrm{GCAG}$ ), and the other two motifs had three and two mismatches, respectively. Three of those motifs were also found in the pycA $-10 /-35$-adjacent regions (Fig. 4c).

Confirmation of the DNA binding capacity of PycR. The $p y c R$ gene from $P$. aeruginosa was placed under the control of the T7 promoter of the pETBlue-2 expression vector and transformed into E. coli Tuner(DE3)pLacI. Overproduction of a $34.6 \mathrm{kDa}$ protein at $37{ }^{\circ} \mathrm{C}$ resulted in extensive inclusion body sequestration of PycR protein after IPTG induction (data not shown). Efforts to resolubilize biologically active protein were not successful; however, lowering the temperature to $32{ }^{\circ} \mathrm{C}$ during expression resulted in lowlevel production of active soluble PycR. The identity of the PycR protein was confirmed by MALDI-TOF MS and by Western blotting using anti-His-tag antibody (data not shown). The 241 bp PCR fragment between $p y c A$ and $p y c R$ was amplified and used for EMSA with cell extracts of E. coli Tuner(DE3)pLacI harbouring pMON3501 (pETBlue-2/ $p y c R)$ (Fig. 5).

The first retarded band representing DNA-protein binding activity was detected in a gel-shift assay containing different concentrations of PycR extracts (Fig. 5, lanes $1-3)$. In this case, the shifting of bands was obtained with an excess of PycR protein. However, we noted a reduction of intensity of the binding complex with lower 

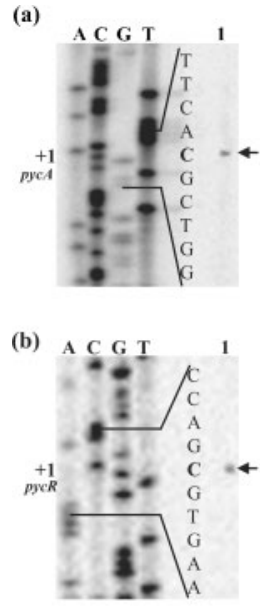

(c) 5' GATCTtCTTGATCACGGaGGTCTCCCTCttCGGGGTtGGGaaCCTGGTaCGGTCGATCCG $\mathbf{3}$ 3 CTAGAAGAACTAGTGCCTCCAGAGGGAGTTGCCCCAACCCTTGGACCATGCCAGCTAGGC $\mathbf{5}$

$$
\text { I } \quad K \quad K \quad \text { I } V \leftarrow \text { PA5436(pycA) }
$$

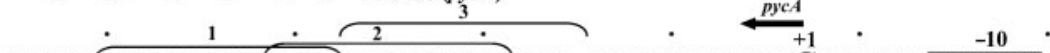
GATATtCCGGTCGCtGCatGACCGGCaGGCaGCTCCCGGTCGCACTTTTACCCTACCCCC

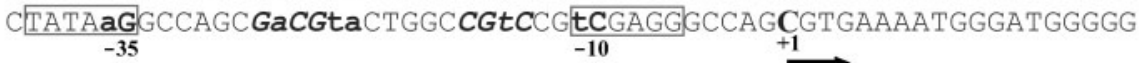

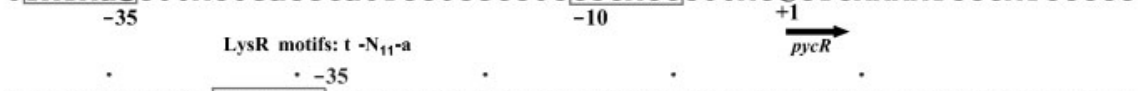

GCGAGGG tGA ttAACAAAAaTCaaTAATTATTGGGA tAGCCATtAGAAaAgCTTtaTAGT CGCTCCCACTAATTGTTTTAGTTATTAATAACCCTATCGGTAATCTTTTCGAAATATCA

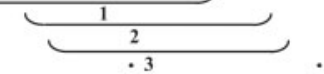

CGCCCGaCCGATCTCGGTCAGAGTGTGACTGGAATGCGTAAGtCGtTGATGCGTaTGaCATTA GCGGGCTGGCTAGAGCCAGTCTCACACTGACCTTACGCATTCAGCAACTACGCATACTGTAAT

$\operatorname{PA5437(pycR)\rightarrow }$ M R M T L

Fig. 4. Determination of the $p y c A(a)$ and $p y c R(b)$ transcriptional start sites using primer extension analysis. Lane 1 contains a primer extension completed using RNA from $P$. aeruginosa strain PAO1 containing the pMON3500 plasmid (pUCP19/pycR), and sequencing reaction lanes are labelled according to nucleotide $(A, C, G$ or $T)$. The extension products are indicated by the arrow for each gene, corresponding to nucleotides -88 and -127 relative to the $p y c A$ and $p y c R$ initiation codons, respectively (c). The directions of $p y c A$ and $p y c R$ transcription with their respective start sites $(+1)$ are indicated by arrows, and putative -10 and -35 sequences are boxed. The GTG/ATG of the pyc $A$ and pycR genes, the direction of translation of their respective proteins, and putative ribosome-binding sites (Shine-Dalgarno, SD) are also indicated. A typical LysR motif $\left[(T)-\mathrm{N}_{11}-(A)\right]$ was found three times in both $p y c A$ and $p y c R-10 /-35$ regulatory regions and is indicated by brackets (c). Only the second pyc $R$ motif had perfect inverted repeats $\mathrm{C}(\mathrm{T}) \mathrm{GC}-\mathrm{N}_{7}-\mathrm{GC}(\mathrm{A}) \mathrm{G}$ (bold italic type), while the two other motifs had two mismatches. $A$ total of 15 putative LysR motifs were found in the whole intergenic sequence ( $T$ and $A$ of each motif are in lower-case bold type).

concentrations of PycR (at $5.4 \mu \mathrm{g}$ protein extract; Fig. 5, lane 3), which suggested concentration-dependent binding. The second migrating band obtained in the gel-shift assay was probably non-specific, because it was weakly detectable in protein extracts from the control strains containing the plasmid vector only (Fig. 5, lanes 9-10). In addition, the increased intensity of this band with lower PycR protein concentrations indicated that this complex was nonspecific and due probably to other proteins present in the crude E. coli extract. To confirm PycR binding specificity in the first complex, a chase experiment using an unlabelled specific DNA probe was used in a competition assay and mixed with labelled DNA. As depicted in Fig. 5, lanes 4-6, the decrease in the intensity of the signal correlated with the increase in unlabelled probe acting as a specific competitor. These data indicated that only the first complex is specific for PycR binding when sufficient amounts of specific DNA and PycR are provided for optimal complex formation and equilibrium. No binding activity was detected in a binding assay without protein (Fig. 5, lane 7). The first binding complex was observed with non-induced culture (Fig. 5, lane 8), indicating a basal level of PycR expression. Since almost all LysR-like regulators act in the presence of a coinducer, either PycR interacts with specific DNA in the absence of a coinducer or the coinducer was present in E. coli cell extracts. This could also explain the absence of binding activity when using purified PycR.

\section{Microarray and qRT-PCR analysis of genes regulated by PycR}

To evaluate the role of PycR in $P$. aeruginosa global gene expression, we compared the transcriptomes of mid-exponential phase $\left(\mathrm{OD}_{600}=0.4\right)$ PAO1 and $\Delta p y c R$ strains using Affymetrix GeneChips. As listed in Table 2, the $\Delta p y c R$ mutant strain showed 34 genes affected in their expression; 17 genes were found to be upregulated and 17 genes were repressed.

We noted that the most important changes were in the transcription levels of $p y c A$ and $p y c B$, encoding two pyruvate carboxylase subunits, providing evidence that $p y c R$ regulates these two genes. These genes were repressed -5.7 and -7.5 -fold, respectively in the $\Delta p y c R$ mutant strain (hence, these genes would be induced in the wildtype by PycR). These data confirm that PycR regulates these two divergently transcribed genes. To validate the results of GeneChip analysis, we tested, by GRT-PCR, the expression of six genes found to be repressed and one gene found to be upregulated. As shown in Table 2, we obtained the same expression patterns with slightly lower expression fold changes between PAO1 and $\Delta p y c R$ strains.

\section{Influence of PycR regulation on overall metabolic activities}

A metabolomics analysis of the $P$. aeruginosa $\Delta p y c R$ mutant strain was done using PMs, which provide a $2 \mathrm{D}$ array 


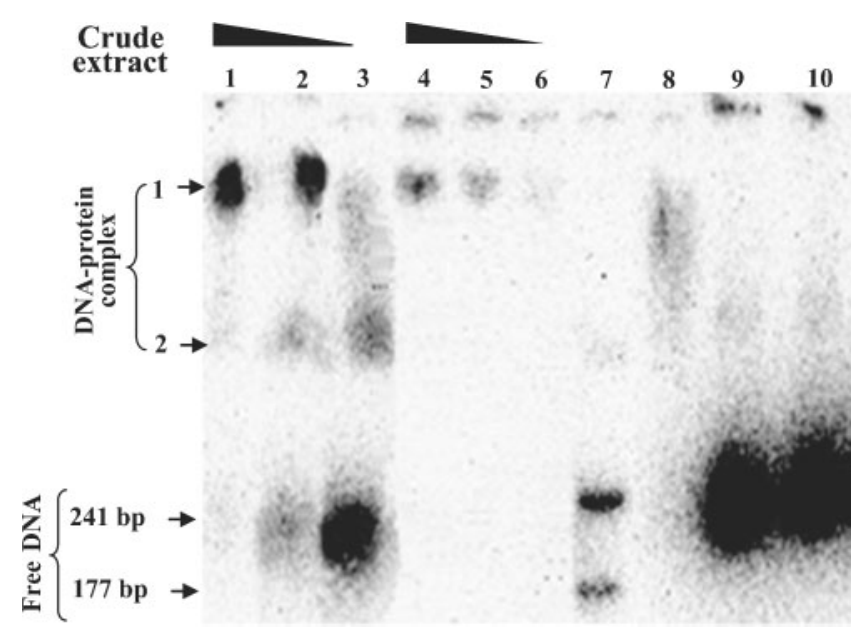

Fig. 5. EMSA demonstrating PycR expression in E. coli and its DNA binding activity to the $p y c A-p y c R$ intergenic region. Crude protein extracts prepared from $E$. coli Tuner(DE3)pLacl carrying

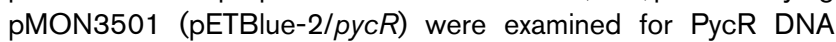
binding activity in the presence of $100 \mathrm{pM}$ specific and nonspecific DNA probes with 43.2, 32.4 and $5.4 \mu \mathrm{g}$ PycR protein extract (lanes 1-3). Binding assays in lanes $4-6$ were performed in the presence of unlabelled specific competitor DNA. These samples contained $100 \mathrm{pM}$ specific DNA probe with $64.8,48.6$ and $43.2 \mu \mathrm{g}$ PycR protein extract using 4.7, 23.5 and $28.2 \mathrm{ng}$ unlabelled specific competitor DNA, respectively. Lane 7 contained no protein and $241 \mathrm{bp}$ specific and $177 \mathrm{bp}$ non-specific free DNA probes. Extracts from non-induced culture (lane 8) and protein extracts from $E$. coli containing the pETBlue-2 plasmid before (lane 9) or after IPTG induction (lane 10) served as controls.

technology for analysis of live cells to measure hundreds of cellular properties simultaneously (Bochner et al., 2001). As shown in Table 3, the most important changes were observed on PM1 and PM2 plates measuring the catabolic functions for carbon utilization. In PM1, the $P$. aeruginosa $\triangle p y c R$ mutant strain had lost its capacity to metabolize $N$ acetyl-D-glucosamine, potentially involved in biofilm formation, as well as glycerol, $\alpha$-ketobutyric acid, $\alpha$ hydroxybutyric acid, acetoaccetic acid and citric acid. There were no differences between the PAO1 wild-type and the PAO1 $\Delta p y c R$ mutant strains on PM4 plates measuring phosphorus and sulfur utilization.

\section{DISCUSSION}

We report here that inactivation of the LysR-type transcriptional regulator encoded by PA5437 (now called PycR) caused serious attenuation of $P$. aeruginosa in vivo and had an effect on the expression of several virulence factors, such as lipolytic activity and biofilm formation. We also showed that PycR participates in regulation of genes implicated in fatty acid biosynthesis, in bacterial response to anaerobiosis and nitrate utilization, in biofilm formation and in the modulation of genes regulated by QS.

Transcriptomics analysis and qRT-PCR confirmed that PycR is required for expression of the divergently transcribed $p y c A B$ genes, which encode $\alpha 4 \beta 4$-type pyruvate carboxylase subunits (Lai et al., 2006). Pyruvate carboxylase (PYC) is an ecologically, medically and industrially important enzyme. PYC catalyses ATP-dependent carboxylation of pyruvate to oxaloacetate, and is responsible for replenishing oxaloacetate for continued operation of the tricarboxylic acid cycle (Jitrapakdee \& Wallace, 1999; Segura \& Espin, 2004). Also, it serves gluconeogenic, glycerogenic and anaplerotic roles, which are often vital for cell survival (Branson et al., 2002). Most bacterial and all eukaryotic PYCs are of the $\alpha 4$ type, and each subunit carries both the PYCA and PYCB domains (Jitrapakdee \& Wallace, 1999; Lim et al., 1988; Mukhopadhyay et al., 1998; Samols et al., 1988). Since P. aeruginosa PYC is of the $\alpha 4 \beta 4$ type and different from eukaryotic $\alpha 4$ PYCs, it represents a potent antimicrobial target. The PYC activity has been detected in cell extracts of $P$. aeruginosa strain PAO (Phibbs et al., 1974). Specific activities were minimal when cells were grown on casamino acids, acetate or succinate, but were three to fourfold higher when cells were grown in glucose, gluconate, glycerol, lactate or pyruvate minimal media. This enzymic reaction is dependent on pyruvate, ATP and $\mathrm{Mg}^{2+}$, but is not affected by either the presence or the absence of acetyl CoA (Phibbs et al., 1974). The partial growth deficiency of the $P$. aeruginosa $\triangle p y c R$ mutant in glucose minimal media suggests the involvement of PycR in PYC regulation.

Lipases are enzymes that catalyse both the formation and the cleavage of long-chain acylglycerols (Jaeger et al., 1999), and they are important in pathogenicity and biofilm formation (Stehr et al., 2003). PMs showed that the $P$. aeruginosa $\triangle p y c R$ mutant cannot utilize glycerol, $\alpha$ ketobutyric, $\alpha$-hydroxybutyric, acetoaccetic and citric acids. In vitro experiments and transcriptomics have demonstrated that the $p y c R$ mutation has some effects on lipolytic activities, and may cause fatty acid biosynthesis (FAB) perturbation and the accumulation of long-chain fatty acids, which repress lipA/H expression (Rosenau \& Jaeger, 2000). In transcriptomics analysis, PA4200, homologous to the YtnP lipase of Bacillus subtilis, was repressed by PycR. The $p y c R$ mutation can be complemented in trans and can fully restore lipolytic activity, indicating its importance in modulation of these virulence determinants.

Only moderate effects of PycR mutation on biofilm formation were demonstrated by in vitro experiments. GeneChip analysis showed that five genes influenced by PycR, PA0049, PA0170, PA0171, PA2130 and PA3540, were implicated in biofilm formation. The PycR activation of PA0171 was also confirmed by qRT-PCR. PA0171 has been shown to be involved in twitching motility (Shan et al., 2004) and to be under AlgR activation during the mid-exponential phase of growth (Lizewski et al., 2004). 
Table 2. Global analysis using Affymetrix microarrays and qRT-PCR of genes differentially regulated by the $P$. aeruginosa PycR transcriptional regulator

Affymetrix microarrays and qRT-PCR assays were done in duplicate using RNA from mid-exponential phase cells. Statistically significant $(P \leqslant 0.05)$ values obtained with the unpaired $t$ test for qRT-PCR analysis are indicated with asterisks.

\begin{tabular}{|c|c|c|c|}
\hline \multirow[t]{2}{*}{ Gene } & \multirow[t]{2}{*}{ Description } & \multicolumn{2}{|c|}{ Fold change } \\
\hline & & Affymetrix & qRT-PCR \\
\hline PA0049 & Hypothetical protein & +2.9 & \\
\hline PA0262 & Conserved hypothetical protein & +3.8 & \\
\hline PA0361 & Probable gamma-glutamyltranspeptidase precursor & +2.3 & \\
\hline PA0704 & Probable amidase & +3.0 & \\
\hline PA1391 & Probable glycosyl transferase & +2.1 & \\
\hline PA2109 & Hypothetical protein & +8.7 & \\
\hline PA2110 & Hypothetical protein & +5.3 & \\
\hline PA2111 & Hypothetical protein & +5.2 & \\
\hline PA2112 & Conserved hypothetical protein & +6.2 & \\
\hline PA2113 & Probable porin & +4.3 & \\
\hline PA2114 & Probable MFS transporter & +6.1 & $+4.7^{\star}$ \\
\hline PA2116 & Conserved hypothetical protein & +3.8 & \\
\hline PA2372 & Hypothetical protein & +2.5 & \\
\hline PA2449 & Probable transcriptional regulator & +2.9 & \\
\hline PA3540 & algD, GDP-mannose 6-dehydrogenase & +2.0 & \\
\hline PA4200 & Hypothetical protein & +3.9 & \\
\hline PA4724 & Probable aminoacyl-tRNA synthetase (class I) & +2.7 & \\
\hline PA0170 & Hypothetical protein & -3.3 & \\
\hline PA0171 & Hypothetical protein & -3.2 & $-1.8^{\star}$ \\
\hline PA0523 & nor $C, \mathrm{NO}$ reductase subunit $\mathrm{C}$ & -3.4 & -2.0 \\
\hline PA0524 & norB, NO reductase subunit B & -3.8 & -2.6 \\
\hline PA0894 & Hypothetical protein & -2.4 & \\
\hline PA1740 & Hypothetical protein & -2.5 & \\
\hline PA2130 & Probable fimbrial biogenesis usher protein & -2.5 & \\
\hline PA2171 & Hypothetical protein & -2.3 & \\
\hline PA2189 & Hypothetical protein & -2.7 & \\
\hline PA2209 & Hypothetical protein & -2.3 & \\
\hline PA3336 & Probable MFS transporter & -2.5 & \\
\hline PA3392 & nos $Z$, nitrous-oxide reductase precursor & -3.1 & -1.6 \\
\hline PA4033 & Hypothetical protein & -3.4 & \\
\hline PA4155 & Hypothetical protein & -2.4 & \\
\hline PA4820 & Hypothetical protein & -2.8 & \\
\hline PA5435 & $p y c B$, pyruvate carboxylase subunit $\mathrm{B}$ & -7.5 & $-2.9^{*}$ \\
\hline PA5436 & $p y c A$, pyruvate carboxylase subunit $\mathrm{A}$ & -5.7 & $-2.9^{*}$ \\
\hline
\end{tabular}

The PA2130 gene, activated by PycR and recently designated $с и p A$, encodes a probable fimbrial biogenesis usher protein, part of the gene cluster predicted to encode a novel fimbrial adhesin involved in biofilm formation (Vallet et al., 2001). This system was found to be induced during anaerobic growth with nitrate (see Supplementary Fig. S1) (Filiatrault et al., 2005). In this study, PA0049 and PA3540 were repressed by PycR. The hypothetical PA0049 was induced in developing biofilms (Waite et al., 2005) and repressed during anaerobic growth (Filiatrault et al., 2005). PA3540 GDP-mannose 6-dehydrogenase AlgD was induced by mucoidy and by confluent biofilm (Firoved et al., 2004; Waite et al., 2005). Furthermore, metabolomics has identified that the $\Delta p y c R$ mutant cannot use $N$-acetyl-
D-glucosamine, although its capacity to use D-galactose is enhanced. Both compounds are important for biofilm formation. D-Galactose is known to reverse the coaggregations of some oral bacteria (Kolenbrander \& Andersen, 1989).

The viability of $P$. aeruginosa robust anaerobic biofilms requires rhl QS and nitric oxide (NO) reductase to modulate or prevent accumulation of toxic NO, a byproduct of anaerobic respiration (Yoon et al., 2002). NO reductase has an important role in the protection of pathogenic bacteria against $\mathrm{NO}$, a toxic free radical produced by macrophages to kill invading micro-organisms (Baek et al., 2004). A group of genes shown to be regulated 
Table 3. PM (Biolog) analysis of the $P$. aeruginosa $\Delta p y c R$ mutant indicating its capacity to metabolize various carbon and nitrogen sources

\begin{tabular}{|ll|}
\hline $\begin{array}{l}\text { Non-metabolized (attenuated) } \\
\text { carbon or nitrogen source }\end{array}$ & $\begin{array}{c}\text { Highly metabolized (overused) } \\
\text { carbon or nitrogen source }\end{array}$ \\
\hline PM1 (carbon) & Saccharic acid \\
$N$-Acetyl-D-glucosamine & D-Galactose \\
Glycerol & Mucic acid \\
$\alpha$-Ketobutyric acid & Tricarballylic acid \\
$\alpha$-Hydroxybutyric acid & D-Galacturonic acid \\
Acetoacetic acid & \\
Citric acid & \\
PM2 (carbon) & DL-Carnitine \\
Gelatin & \\
4 -Hydroxybenzoic acid & \\
L-Isoleucine & \\
PM3 (nitrogen) & L-Phenylethylamine \\
& D-Galactosamine \\
\hline
\end{tabular}

by PycR are implicated in anaerobic respiration, denitrification and nitrogen metabolism, and are QS regulated. Three genes activated by $\mathrm{PycR}$ were $\mathrm{NO}$ reductase subunits $\mathrm{C}$ and $\mathrm{B}$ norCB (PA0523 and PA0524), which perform denitrification and participate in protection against nitrosative stress (Philippot, 2005), and the nitrous-oxide reductase nos $Z$ (PA3392), which reduces nitrate $\left(\mathrm{NO}_{3}^{-}\right)$and nitrite $\left(\mathrm{NO}_{2}^{-}\right)$ to $\mathrm{NO}$, nitrous oxide $\left(\mathrm{N}_{2} \mathrm{O}\right)$ and dinitrogen $\left(\mathrm{N}_{2}\right)$ (Arai et al., 2003). The differential expression of these three genes (PA0523, PA0524 and PA3392) was confirmed by qRT-PCR, but the differences in fold changes between wild-type and $\triangle p y c R$ mutant were not significant in qRT-PCR experiments. Furthermore, the $p y c A B$ gene products have been shown to be repressed by nitrate (Supplementary Fig. S1) (Filiatrault et al., 2005).

The PA2109-PA2114 operon was repressed by PycR. The repression of PA2114 expression was confirmed by qRTPCR (Table 2). PA2114 encodes a probable major facilitator superfamily (MFS) transporter and has recently been shown to be upregulated in developing biofilms (Waite et al., 2005). In contrast, PA2110 and PA2112-2114 were found to be repressed during anaerobic growth with nitrate, and PA2110, PA2112 and PA2114 were induced in cultures grown aerobically with or without nitrate (Filiatrault et al., 2005). PMs of the P. aeruginosa $\Delta p y c R$ mutant also demonstrated that three metabolic pathways involved in nitrogen utilization were induced: the utilization of L-asparagine, $\beta$-phenylethylamine and $\mathrm{D}$ galactosamine.

This study provides evidence that the $P$. aeruginosa transcriptional regulator $\mathrm{PycR}$ is necessary for in vivo maintenance, has an indirect effect on virulence factors such as lipase/esterase and biofilm production, and modulates the expression of genes implicated in lipid metabolism, anaerobic respiration, biofilm formation and the expression of some QS-regulated genes (Supplementary Fig. S1). PycR positively controls the expression of two subunits of pyruvate carboxylase A and B (PA5435-5436). The NO reductase (nor $B, C)$ and nitrous-oxide reductase (nos $Z$ ) genes, genes involved in biofilm formation, and some QS-regulated genes were also moderately induced by PycR. PycR represses the genes potentially implicated in anaerobic respiration, lipolytic activity, and nitrogen and lipid metabolism. Thus, $\mathrm{PycR}$ is an important regulator, which plays a role in $P$. aeruginosa lung pathogenesis and represents a potential target for development of novel metabolic-type antimicrobials.

\section{ACKNOWLEDGEMENTS}

We express our gratitude to K.-E. Jaeger from the University of Düsseldorf for providing lipase/esterase-defective mutants, to G. A. O'Toole from Dartmouth Medical School Hanover for the PA14sad36 biofilm-defective mutant, to R. de la Durantaye for excellent technical assistance in animal manipulations, and to J. Renaud for assistance in DNA sequencing. Work on STM in R. C. L.'s laboratory is funded by the Canadian Institute for Health Research as part of the CIHR Genomics Program, and as a Research Scholar of Exceptional Merit. I. K.-I. is a PhD scholar from Le Fonds de la Recherche en Santé du Québec (FRSQ). M.W.'s laboratory is funded by NIH (\#1P20RR15564-01) and a grant from the Oklahoma Center for the Advancement of Science and Technology.

\section{REFERENCES}

Arai, H., Mizutani, M. \& Igarashi, Y. (2003). Transcriptional regulation of the nos genes for nitrous oxide reductase in Pseudomonas aeruginosa. Microbiology 149, 29-36. 
Baek, S. H., Rajashekara, G., Splitter, G. A. \& Shapleigh, J. P. (2004). Denitrification genes regulate Brucella virulence in mice. J Bacteriol 186, 6025-6031.

Bochner, B. R., Gadzinski, P. \& Panomitros, E. (2001). Phenotype microarrays for high-throughput phenotypic testing and assay of gene function. Genome Res 11, 1246-1255.

Bowtell, D. \& Sambrook, J. (2003). DNA Microarrays: a Molecular Cloning Manual. Cold Spring Harbor, NY: Cold Spring Harbor Laboratory.

Branson, J. P., Nezic, M., Wallace, J. C. \& Attwood, P. V. (2002). Kinetic characterization of yeast pyruvate carboxylase isozyme Pyc1. Biochemistry 41, 4459-4466.

Carty, N. L., Rumbaugh, K. P. \& Hamood, A. N. (2003). Regulation of toxA by PtxR in Pseudomonas aeruginosa PA103. Can J Microbiol 49, 450-464.

Cash, H. A., Woods, D. E., McCullough, B., Johanson, W. G., Jr \& Bass, J. A. (1979). A rat model of chronic respiratory infection with Pseudomonas aeruginosa. Am Rev Respir Dis 119, 453-459.

deHaseth, P. L., Zupancic, M. L. \& Record, M. T., Jr (1998). RNA polymerase-promoter interactions: the comings and goings of RNA polymerase. J Bacteriol 180, 3019-3025.

Delic-Attree, I., Toussaint, B., Garin, J. \& Vignais, P. M. (1997). Cloning, sequence and mutagenesis of the structural gene of Pseudomonas aeruginosa CysB, which can activate $\operatorname{algD}$ transcription. Mol Microbiol 24, 1275-1284.

Filiatrault, M. J., Wagner, V. E., Bushnell, D., Haidaris, C. G., Iglewski, B. H. \& Passador, L. (2005). Effect of anaerobiosis and nitrate on gene expression in Pseudomonas aeruginosa. Infect Immun 73, 3764-3772.

Firoved, A. M., Wood, S. R., Ornatowski, W., Deretic, V. \& Timmins, G. S. (2004). Microarray analysis and functional characterization of the nitrosative stress response in nonmucoid and mucoid Pseudomonas aeruginosa. J Bacteriol 186, 4046-4050.

Hoang, T. T., Karkhoff-Schweizer, R. R., Kutchma, A. J. \& Schweizer, H. P. (1998). A broad-host-range Flp-FRT recombination system for site-specific excision of chromosomally-located DNA sequences: application for isolation of unmarked Pseudomonas aeruginosa mutants. Gene 212, 77-86.

Holloway, B. W., Krishnapillai, V. \& Morgan, A. F. (1979). Chromosomal genetics of Pseudomonas. Microbiol Rev 43, 73-102.

Jaeger, K. E., Dijkstra, B. W. \& Reetz, M. T. (1999). Bacterial biocatalysts: molecular biology, three-dimensional structures, and biotechnological applications of lipases. Annu Rev Microbiol 53, 315-351.

Jitrapakdee, S. \& Wallace, J. C. (1999). Structure, function and regulation of pyruvate carboxylase. Biochem J 340, 1-16.

Kolenbrander, P. E. \& Andersen, R. N. (1989). Inhibition of coaggregation between Fusobacterium nucleatum and Porphyromonas (Bacteroides) gingivalis by lactose and related sugars. Infect Immun 57, 3204-3209.

Kovacikova, G., Lin, W. \& Skorupski, K. (2005). Dual regulation of genes involved in acetoin biosynthesis and motility/biofilm formation by the virulence activator AphA and the acetate-responsive LysR-type regulator AlsR in Vibrio cholerae. Mol Microbiol 57, 420-433.

Lai, H., Kraszewski, J. L., Purwantini, E. \& Mukhopadhyay, B. (2006). Identification of pyruvate carboxylase genes in Pseudomonas aeruginosa PAO1 and development of a P. aeruginosa-based overexpression system for $\alpha 4$ - and $\alpha 4 \beta 4$-type pyruvate carboxylases. Appl Environ Microbiol 72, 7785-7792.

Lehoux, D. E., Sanschagrin, F. \& Levesque, R. C. (2002). Identification of in vivo essential genes from Pseudomonas aeruginosa by PCR-based signature-tagged mutagenesis. FEMS Microbiol Lett 210, 73-80.
Lehoux, D. E., Sanschagrin, F., Kukavica-Ibrulj, I., Potvin, E. \& Levesque, R. C. (2004). Identification of novel pathogenicity genes by PCR signature-tagged mutagenesis and related technologies. Methods Mol Biol 266, 289-304.

Lim, F., Morris, C. P., Occhiodoro, F. \& Wallace, J. C. (1988). Sequence and domain structure of yeast pyruvate carboxylase. J Biol Chem 263, 11493-11497.

Lizewski, S. E., Schurr, J. R., Jackson, D. W., Frisk, A., Carterson, A. J. \& Schurr, M. J. (2004). Identification of AlgR-regulated genes in Pseudomonas aeruginosa by use of microarray analysis. J Bacteriol 186, 5672-5684.

Mukhopadhyay, B., Stoddard, S. F. \& Wolfe, R. S. (1998). Purification, regulation, and molecular and biochemical characterization of pyruvate carboxylase from Methanobacterium thermoautotrophicum strain $\Delta \mathrm{H}$. J Biol Chem 273, 5155-5166.

O'Toole, G. A. \& Kolter, R. (1998a). Initiation of biofilm formation in Pseudomonas fluorescens WCS365 proceeds via multiple, convergent signalling pathways: a genetic analysis. Mol Microbiol 28, 449-461.

O'Toole, G. A. \& Kolter, R. (1998b). Flagellar and twitching motility are necessary for Pseudomonas aeruginosa biofilm development. Mol Microbiol 30, 295-304.

Phibbs, P. V., Jr, Feary, T. W. \& Blevins, W. T. (1974). Pyruvate carboxylase deficiency in pleiotropic carbohydrate-negative mutant strains of Pseudomonas aeruginosa. J Bacteriol 118, 999-1009.

Philippot, L. (2005). Denitrification in pathogenic bacteria: for better or worst? Trends Microbiol 13, 191-192.

Potvin, E., Lehoux, D. E., Kukavica-Ibrulj, I., Richard, K. L., Sanschagrin, F., Lau, G. W. \& Levesque, R. C. (2003). In vivo functional genomics of Pseudomonas aeruginosa for high-throughput screening of new virulence factors and antibacterial targets. Environ Microbiol 5, 1294-1308.

Rosenau, F. \& Jaeger, K. (2000). Bacterial lipases from Pseudomonas: regulation of gene expression and mechanisms of secretion. Biochimie 82, 1023-1032.

Rozen, S. \& Skaletsky, H. (2000). Primer3 on the WWW for general users and for biologist programmers. Methods Mol Biol 132, 365-386.

Rukholm, G., Mugabe, C., Azghani, A. O. \& Omri, A. (2006). Antibacterial activity of liposomal gentamicin against Pseudomonas aeruginosa: a time-kill study. Int J Antimicrob Agents 27, 247-252.

Sambrook, J. \& Russell, D. W. (2001). Molecular Cloning: a Laboratory Manual, 3rd edn. Cold Spring Harbor, NY: Cold Spring Harbor Laboratory.

Samols, D., Thornton, C. G., Murtif, V. L., Kumar, G. K., Haase, F. C. \& Wood, H. G. (1988). Evolutionary conservation among biotin enzymes. J Biol Chem 263, 6461-6464.

Schell, M. A. (1993). Molecular biology of the LysR family of transcriptional regulators. Annu Rev Microbiol 47, 597-626.

Schuster, M., Lostroh, C. P., Ogi, T. \& Greenberg, E. P. (2003). Identification, timing, and signal specificity of Pseudomonas aeruginosa quorum-controlled genes: a transcriptome analysis. J Bacteriol 185, 2066-2079.

Schuster, M., Urbanowski, M. L. \& Greenberg, E. P. (2004). Promoter specificity in Pseudomonas aeruginosa quorum sensing revealed by DNA binding of purified LasR. Proc Natl Acad Sci U S A 101, 15833-15839.

Segura, D. \& Espin, G. (2004). Inactivation of $p y c A$, encoding pyruvate carboxylase activity, increases poly- $\beta$-hydroxybutyrate accumulation in Azotobacter vinelandii on solid medium. Appl Microbiol Biotechnol 65, 414-418.

Shan, Z., Xu, H., Shi, X., Yu, Y., Yao, H., Zhang, X., Bai, Y., Gao, C., Saris, P. E. \& Qiao, M. (2004). Identification of two new genes 
involved in twitching motility in Pseudomonas aeruginosa. Microbiology 150, 2653-2661.

Simon, R., Priefer, U. \& Pühler, A. (1983). A broad host range mobilization system for in vivo genetic engineering: transposon mutagenesis in Gram negative bacteria. Bio/technology (NY) 1, 784-791.

Stehr, F., Kretschmar, M., Kröger, C., Hube, B. \& Schäfer, W. (2003). Microbial lipases as virulence factors. J Mol Catal, B Enzym 22, 347-355.

Vallet, I., Olson, J. W., Lory, S., Lazdunski, A. \& Filloux, A. (2001). The chaperone/usher pathways of Pseudomonas aeruginosa: identification of fimbrial gene clusters (сир) and their involvement in biofilm formation. Proc Natl Acad Sci U S A 98, 6911-6916.

van Heeckeren, A. M. \& Schluchter, M. D. (2002). Murine models of chronic Pseudomonas aeruginosa lung infection. Lab Anim 36, 291-312.

Wade, D. S., Calfee, M. W., Rocha, E. R., Ling, E. A., Engstrom, E., Coleman, J. P. \& Pesci, E. C. (2005). Regulation of Pseudomonas quinolone signal synthesis in Pseudomonas aeruginosa. J Bacteriol 187, 4372-4380.
Waite, R. D., Papakonstantinopoulou, A., Littler, E. \& Curtis, M. A. (2005). Transcriptome analysis of Pseudomonas aeruginosa growth: comparison of gene expression in planktonic cultures and developing and mature biofilms. J Bacteriol 187, 6571-6576.

West, S. E., Schweizer, H. P., Dall, C., Sample, A. K. \& RunyenJanecky, L. J. (1994). Construction of improved EscherichiaPseudomonas shuttle vectors derived from pUC18/19 and sequence of the region required for their replication in Pseudomonas aeruginosa. Gene 148, 81-86.

Wilhelm, S., Tommassen, J. \& Jaeger, K. E. (1999). A novel lipolytic enzyme located in the outer membrane of Pseudomonas aeruginosa. $J$ Bacteriol 181, 6977-6986.

Yoon, S. S., Hennigan, R. F., Hilliard, G. M., Ochsner, U. A., Parvatiyar, K., Kamani, M. C., Allen, H. L., DeKievit, T. R., Gardner, P. R. \& other authors (2002). Pseudomonas aeruginosa anaerobic respiration in biofilms: relationships to cystic fibrosis pathogenesis. Dev Cell 3, 593-603.

Edited by: W. Bitter 